\title{
Sibling caringscapes: time-space practices of caring within youth-headed households in Tanzania and Uganda
}

Article

Accepted Version

Evans, R. (2012) Sibling caringscapes: time-space practices of caring within youth-headed households in Tanzania and Uganda. Geoforum, 43 (4). pp. 824-835. ISSN 0016-7185 doi: https://doi.org/10.1016/j.geoforum.2012.02.004 Available at https://centaur.reading.ac.uk/27842/

It is advisable to refer to the publisher's version if you intend to cite from the work. See Guidance on citing.

To link to this article DOI: http://dx.doi.org/10.1016/j.geoforum.2012.02.004

Publisher: Elsevier

All outputs in CentAUR are protected by Intellectual Property Rights law, including copyright law. Copyright and IPR is retained by the creators or other copyright holders. Terms and conditions for use of this material are defined in the End User Agreement.

$\underline{\text { www.reading.ac.uk/centaur }}$ 
Central Archive at the University of Reading

Reading's research outputs online 
Revised article submitted to Geoforum

Title: Sibling caringscapes: time-space practices of caring within youth-headed households in Tanzania and Uganda

Author: Ruth Evans, Department of Geography \& Environmental Science, University of Reading

\section{Contact details:}

Dr. Ruth Evans

Lecturer in Human Geography

Department of Geography and Environmental Science

University of Reading

Whiteknights PO Box 227

Reading RG6 6AB

UK

Email: r.evans@reading.ac.uk 


\section{Sibling caringscapes: time-space practices of caring within youth-headed households in}

\section{Tanzania and Uganda}

\section{Abstract (213 words)}

This paper investigates the time-space practices of young people caring for their siblings in youth-headed households affected by AIDS in Tanzania and Uganda. Based on qualitative exploratory research with young people heading households, their siblings, NGO workers and community members, the article develops the notion of sibling 'caringscapes' to analyse young people's everyday practices and caring pathways through time and space. Participatory time-use data reveals that older siblings of both genders regularly undertake substantial caring tasks at the very high end of the caregiving continuum. Drawing on rhythmanalysis, the paper explores how young people negotiate emotional geographies and temporalities of caring. The competing rhythms of bodies, schooling, work and seasonal agricultural production can result in 'arrhythmia' and time scarcity, which has detrimental effects on young people's health, education, future employment prospects and mobility. Young people's lifecourse transitions are shaped to a large extent by their caring responsibilities, resulting in some young people remaining in a liminal position for considerable periods, unable to make 'successful' transitions to adulthood. Despite structural constraints, however, young people are able to exercise some autonomy over their caring pathways and lifecourse transitions. The research sheds light on the ways that individuals embody the practices, routines and rhythms of everyday life and exercise agency within highly restricted broader landscapes of care.

\section{Key words}

Caring

CRuth Evans 12/01/2012.

Please cite this article as: Evans, R., (2012) 'Sibling caringscapes: Time-space practices of caring within youthheaded households in Tanzania and Uganda', Geoforum, doi:10/1016/j.geoforum.2012.02.004. 
Youth-headed households

Sibling relations

Youth transitions

Tanzania

Uganda

\section{Introduction}

The social arrangements and allocation of resources for the care of vulnerable groups represent a critical challenge for global social policy and international development in the present and in the future. These concerns are reflected in the burgeoning geographies of care literature (Conradson, 2003; Milligan and Wiles, 2010). Although care can be provided at a distance (Silk, 1998), 'proximity' or 'co-presence' is a key feature of most forms of informal care within the family (such as the care of young children, disabled, older or chronically ill people) which require the physical presence of a carer in the same location as the person receiving care (Bowlby et al, 2010, p.3). As Bowlby et al. (2010, p.3) note, this has "clear practical implications for the possibilities of combining paid work and care and for the social organisation of the resources of caring".

Within most time-use surveys and studies of housework and unpaid care work in the minority world, children are conceptualised as 'dependents' and 'care recipients' rather than as 'contributors' or 'caregivers'. This reflects minority world constructions of childhood that usually depict children as "precious rather than useful" (Miller, 2005, p.2). Since the 1990s, however, a growing literature has demonstrated the significant care work that children and 
youth undertake in families affected by chronic illness and disability in the UK, Australia and USA (Becker, 2007; Becker et al., 1998). Comparative research with children caring for parents with HIV has revealed that children undertake broadly similar caring roles in the majority and minority worlds, although the nature of caring tasks and the time taken to perform them differs due to disparities in living standards, basic services and infrastructure (Bauman et al., 2006; Evans and Becker, 2009). Children's caring roles include supporting family members with healthcare, personal care, household chores, childcare and providing emotional and practical support (Evans, 2010). A key difference in the majority world is children's involvement in income earning activities as a replacement for the loss of a parent/adult relative's income (Evans and Becker, 2009).

While the bulk of care research focuses on the minority world, a growing literature has explored changing arrangements for the care of chronically ill adults and orphaned children in eastern and southern Africa in response to the devastating impacts of HIV and AIDS on families and communities (Evans and Thomas, 2009; Nyambedha et al., 2003; Robson et al., 2006; Van Blerk and Ansell, 2007a). Research in Tanzania, Kenya, Malawi, Lesotho and Zimbabwe has revealed that young people's caring roles shift along a continuum over time and space (Evans and Becker, 2009; Robson et al., 2006; Skovdal, 2011). In the context of HIV, young people may care for several people of different generations for varying periods of time and intensity (Evans, 2011; Skovdal, 2011). Young people's caring roles may increase or decrease depending on the different care needs of family members and neighbours, the availability of other caregivers, mobility between households and changing access to informal and formal resources in particular places. This reveals the importance of using a time-space framework to analyse young people's caring roles and activities. 
This paper provides insight into time-space practices of sibling caregiving in the context of orphanhood in east Africa. Sibling relationships (and intimate family relations more generally: Valentine, 2008) have been largely overlooked to date within human geography. Anthropological studies in the majority world have revealed children's significant roles in caring for younger siblings (often referred to as 'sibling/child caretaking') in diverse cultural contexts (Cicirelli, 1994; Punch, 2001; Payne, 2009). In many African societies, older siblings are expected to look after their younger siblings without adult supervision, sometimes for considerable periods, in order to free up time for mothers to engage in other social reproductive or productive activities (LeVine et al, 1996). Older siblings' roles in instructing, guiding and playing with their younger siblings when performing household tasks, working on the family farm and engaging in other productive (income-earning) or social reproductive activities (such as fetching water and firewood, bathing siblings, caring for sick family members and so on) are often viewed as an important part of both older and younger children's informal training and socialisation within the family and community. The situation of children and youth providing care for younger siblings in youth-headed households without a co-resident adult relative in eastern and southern Africa, however, is regarded as going beyond the usual cultural expectations of sibling caretaking (Kesby et al., 2006). Young people's roles in 'parenting' their younger siblings without adult supervision are often perceived to have detrimental impacts on their own and younger children's education, health and psychosocial development (Meintjes et al., 2010; Thurman et al., 2008).

This paper uses the framework of 'sibling caringscapes' to conceptualise the spatial and temporal patterning of sibling care in youth-headed households in Tanzania and Uganda. This 
approach seeks to integrate young people's everyday activities of caring with the emotional geographies and reflective positions that young people adopt and negotiate across different locales through time. Drawing on qualitative exploratory research with young people heading households, younger siblings, NGO workers and community members in rural and urban areas of Tanzania and Uganda, I aim to further understandings of time-space practices of caring and the lifecourse transitions that young people negotiate. First, I discuss recent literature and the concepts of 'caringscapes' and 'rhythmanalysis' used to interpret young people's caring practices. Following an overview of the research methods and limitations, I analyse the gender and age-related time-space dynamics of young people's caring activities and routines. I then discuss how emotional geographies of caring intersect with schooling and work time-space patterns and explore young people's embodied experiences of negotiating these competing rhythms. I examine how sibling caring responsibilities affect young people's lifecourse transitions. To conclude, I reflect on how the findings can inform understandings of caregivers' agency and youth transitions and highlight the policy and practice implications.

\section{Time-use data on care work}

Implicit within much of the care literature is the significance of time to socio-spatial practices of care, most notably through daily caregiving routines. Evidence from quantitative time-use surveys in recent decades suggests that an increase in female engagement in paid work in the minority world has not been accompanied by a similarly sized increase in male engagement in unpaid care work (Budlender, 2010a). Although most time-use surveys to date have been conducted in Europe, North America and Australia, United Nations Research Institute for Social Development (UNRISD) analyses of time-use surveys of the population (aged $15-64$ 
years) in Tanzania, South Africa, Argentina, Nicaragua, India and the Republic of Korea broadly support the findings from the minority world. For all countries surveyed, women tend to spend more time on unpaid care work than men and the mean time for women is more than twice that for men. Within the category of unpaid care work, the amount of time reported spent undertaking 'care of persons' is relatively small across all countries (less than one hour per day), which reflects the fact that a much smaller proportion of the population engages in 'care of persons' than in 'housework', in addition to the fact that 'care of persons' is likely to be underreported, particularly where this work (especially childcare) is done simultaneously with other activities (Budlender, 2010a). While time-use surveys are helpful in giving broad indications of gendered patterns of activity, as Budlender (2010b) notes in relation to the care needs of families affected by HIV in Tanzania, time-use surveys cannot tell us much about the high levels of unpaid care work done by a relatively small proportion of the population. This demonstrates the value of qualitative analyses of caring activities that focus on groups who have much greater caring responsibilities than the average person.

Official statistics about the time young people spend on unpaid care work in Sub-Saharan Africa (and other majority world contexts) are currently unavailable. Evidence suggests that between $2 \%$ and $4 \%$ of children take on caring roles in the UK, Australia and USA (Becker, 2007). Of the 175,000 children estimated to be involved in unpaid care within the family in the UK, approximately 29,000 provide more than 20 hours of care per week and 13,000 provide more than 50 hours per week, which is considered to be at the very high end of the caregiving continuum and likely to result in significant negative outcomes for children's education, health and development (Evans and Becker, 2009).

CRuth Evans 12/01/2012.

Please cite this article as: Evans, R., (2012) 'Sibling caringscapes: Time-space practices of caring within youthheaded households in Tanzania and Uganda', Geoforum, doi:10/1016/j.geoforum.2012.02.004. 


\section{Conceptualising time-space practices of caring}

Milligan and Wiles (2010) argue that the concept of 'landscapes of care' has provided a useful lens with which to analyse the multilayered social, emotional, symbolic, physical and material aspects of caring. They define 'landscapes of care' as, "the complex embodied and organizational spatialities that emerge from and through the relationships of care" (ibid, p.740, original emphasis). Spatial practices of care are not only bound up with 'clock time' through daily caregiving routines, but are also inextricably linked to other temporalities, such as 'lived time' and the rhythms of everyday life, bodies, seasons and the lifecourse (Bowlby et al., 2010; Davies, 2001; May and Thift, 2001).

McKie et al. (2002)'s notion of 'caringscapes' is useful in theorising the complex ways that young people negotiate their caring trajectories through time and space and has been fruitfully employed in a range of contexts (Haugen, 2007) besides its original use in conceptualising time-space dimensions of parents' responsibilities for childcare and paid work. A caringscapes perspective seeks to analyse the complex "actualities and possibilities of the social patterning of time-space trajectories through a range of locales significant to caring" (McKie et al., 2002, p. 914). It draws attention to the practical activities of caring, as well as the feelings and subjective positions of different actors involved in caring pathways across different temporal and spatial contexts. The authors suggest that different temporalities are embedded in caringscapes, including "the temporality of the human life course", "the temporality of paid work career paths" and "the temporality of the daily routines of the people and institutions with whom a person habitually interacts" (ibid, 905). Such a perspective highlights the multidimensional, often gendered nature of temporal and spatial frameworks (Bowlby et al., 2010). 
Following Bowlby et al.'s (2010) concept of caringscapes, lifecourse transitions are understood as 'changes in the lives of individuals that are in accordance with the socially constructed life course' (Dewilde, 2003, p.118) which are linked to age, such as leaving school, having children, marriage etc. Recent literature has troubled conventional understandings of such lifecourse transitions and revealed the diverse and often contradictory nature of young people's pathways to 'adulthood' in both the minority and majority world (Christiansen et al., 2006; Valentine, 2003). The caring pathways of young people affected by HIV, in particular, blur the boundaries between 'childhood' and' adulthood', since young people are involved in activities, roles and responsibilities that are usually associated with 'adulthood' while they are still regarded by others as a 'child'(Evans, 2011). While previous work has discussed young people's transitions into caring, this paper focuses on how caring practices may affect young people's socially expected lifecourse transitions and imagined futures.

In addition to adopting a caringscapes perspective, Henri Lefebvre's (2004) 'rhythmanalytical' approach helps to analyse the interdependence or 'reciprocal action' between time and space in everyday life. Lefebvre distinguishes between the repetitions or recurrences of linear time ('clock time' resulting from social practice and human activity) and cyclical time (resulting from nature, such as seasons, days, nights, biological rhythms of sleep, hunger, bodily changes etc.) (Elden, 2004; Simonsen, 2005). The body is central to Lefebvre's mode of analysis, as the point of contact where diverse social and biological rhythms co-exist, referred to as 'polyrhythmia'. Lefebvre's $(2004$, p.68) notion of 'arrhythmia' refers to conflict or de-synchronisation between different rhythms: "a divergence in time, in 
space, in the use of energies". Alongside stress and emotional pressures caused by such conflicts, Strazdins et al. (2011, p.549) suggest that time scarcity (defined as 'the feeling of not enough time [...] people's experience of rushing and pressure as well as the quanta of time spent on given practices') prevents behaviours essential for good health. They argue that time scarcity may have particularly negative outcomes for the health of people who are both time and income poor. Although a significant body of work discusses timespace and geographies of temporality in a range of contexts (Massey, 2005; May and Thrift, 2001), few studies to date have examined the temporalities of young people's everyday lives (for exceptions, see Ansell et al., 2011; Kullman and Palludan, 2011; Robson, 2004). By analysing the time-space practices of sibling caregiving, this paper responds to Horton and Kraftl's (2006, p.87) call to explore the mundane, everyday events, 'happenings' and ongoing practices in young people's lives in order to "talk back" to wider theorisations of "performance, performativity, everydayness and practice".

\section{The research}

A youth-focused qualitative participatory methodology was considered most appropriate to gain an in-depth understanding of the perspectives of this marginalised group of young people, community members and NGO workers supporting them ${ }^{1}$. A small purposive sample of young people (aged under 25) who cared for their siblings in youth-headed households ${ }^{2}$

\footnotetext{
${ }^{1}$ The research conforms to the ethical protocols of the Social Research Association and British Sociological Association and ethical approval was granted by the University of Reading's Research Ethics Committee in 2008 and 2009.

${ }^{2}$ In this research, youth-headed households are defined as households where children and young people live with siblings, cousins or other young relatives without a co-resident adult (aged 25 or over). All the co-resident members of the household were therefore aged under 25 years, which corresponds to the United Nations definition of youth as aged 15-24 years (UN, 2007). I recognise the ORuth Evans 12/01/2012.

Please cite this article as: Evans, R., (2012) 'Sibling caringscapes: Time-space practices of caring within youthheaded households in Tanzania and Uganda', Geoforum, doi:10/1016/j.geoforum.2012.02.004.
} 
was identified through contact with NGOs working in Kampala and the districts of Mpigi, Mukono, Wakiso and Luwero in the Central Region of Uganda and in Nshamba, Kagera region, Mbeya and Dar es Salaam in Tanzania. These regions were selected due to very high levels of orphanhood within Tanzania and Uganda and differences in NGO approaches to supporting orphans and vulnerable children. Mbeya region had the highest rate of orphanhood in Tanzania, where $17 \%$ of children were estimated to have lost one or both parents; the figures were $13 \%$ in Dar es Salaam and 11\% in Kagera (TACAIDS et al., 2005). In Uganda, the highest percentage of orphaned children lived in the Central region in 2005 ( $18 \%$ of children had lost one or both parents) and $15 \%$ of children were estimated to be orphans in Kampala (UBOS, 2006).

Semi-structured interviews were conducted with 14 young people (9 girls, 5 boys, aged 12 23) from 11 youth-headed households and one grandparent-headed household (which became a youth-headed household during the course of the research) at NGO centres or in their homes and with 15 project workers from five organisations in 2008 (see Table 1). Focus groups were conducted with a further 15 young people and five community leaders and NGO staff in Tanzania at NGO centres. In Tanzania, I conducted the interviews, focus groups and workshops in Kiswahili (with some interpretation into a local language from NGO workers in one interview) and the data were transcribed and translated into English by translators. In Uganda, I conducted the interviews in English with interpretation to/from Luganda provided problematic nature of universal age-based definitions of youth (Valentine, 2003); while local understandings of key markers of childhood, youth and adulthood were associated with particular lifestages and competencies such as completion of secondary education, financial independence, marriage and childbirth, in focus groups, young people and community members also pointed to the universal age-based definition of children as specified in the UN Convention on the Rights of the Child as all those aged under 18 and defined adults as all those aged 18 years and over.

CRuth Evans 12/01/2012.

Please cite this article as: Evans, R., (2012) 'Sibling caringscapes: Time-space practices of caring within youthheaded households in Tanzania and Uganda', Geoforum, doi:10/1016/j.geoforum.2012.02.004. 
by NGO workers, although some young people spoke English. Audio-recordings were later transcribed.

Following transcription and translation, the transcripts were reviewed and the data were thematically analysed to identify commonalities in young people's experiences of heading households as well as similarities and differences between young people's experiences according to gender, age, sibling birth order, rural/urban location and country of residence. Key themes identified from the data, informed by previous literature on young people's caring roles, included: transitions into caring; the range of caring tasks young people engaged in; positive and negative outcomes of caring on young people's family relations, education, health and emotional wellbeing, social lives and involvement in the community; NGO support; and young people's future lives, priorities and opportunities. Discussion of these overarching themes informed the writing of an accessible summary for participants.

Following data analysis, participatory workshops were held in the three main research locations of Kampala, Mbeya and Nshamba, Kagera region with a total of 34 young people (17 siblings heading households and 17 of their younger siblings) and 25 NGO workers and 14 community members in 2009 (see Table 1). Young people who had participated in interviews were invited to participate in a one-day workshop with one or more of their younger siblings. The workshops used focus groups with younger and older siblings and participatory diagramming (Kesby, 2000) such as a time-use exercise and ranking of identified needs and priorities, to verify initial findings, further develop understandings of the issues and to co-produce creative research outputs, including art posters and video-recorded drama and music performances of key research messages. Young people's diagrams, ORuth Evans 12/01/2012.

Please cite this article as: Evans, R., (2012) 'Sibling caringscapes: Time-space practices of caring within youthheaded households in Tanzania and Uganda', Geoforum, doi:10/1016/j.geoforum.2012.02.004. 
performances and priorities were presented and discussed further in workshops with NGO workers and community leaders in their locality the following day.

ORuth Evans 12/01/2012.

Please cite this article as: Evans, R., (2012) 'Sibling caringscapes: Time-space practices of caring within youthheaded households in Tanzania and Uganda', Geoforum, doi:10/1016/j.geoforum.2012.02.004. 
Table 1: Methods and sample of participants in Tanzania and Uganda

\begin{tabular}{|c|c|c|}
\hline Method & Number of participants & Breakdown of participants \\
\hline $\begin{array}{l}\text { Semi- } \\
\text { structured } \\
\text { interviews } \\
\text { (group and } \\
\text { individual) }\end{array}$ & $\begin{array}{l}12 \text { interviews with } 16 \text { young people (aged } \\
\text { 12-23) from: } \\
\text { - } 7 \text { youth-headed households in Uganda } \\
\text { - } 5 \text { youth-headed households in } \\
\text { Tanzania } \\
6 \text { interviews with } 15 \text { NGO staff from } 5 \\
\text { organisations }\end{array}$ & $\begin{array}{l}5 \text { young men heading households } \\
9 \text { young women heading households } \\
2 \text { younger siblings in youth-headed households }\end{array}$ \\
\hline Focus groups & $\begin{array}{l}3 \text { focus groups in Tanzania with: } \\
\text { - } 2 \text { with } 15 \text { young people } \\
\text { - } 1 \text { with } 2 \text { NGO staff and } 3 \text { community } \\
\quad \text { leaders }\end{array}$ & $\begin{array}{l}3 \text { young men heading households } \\
2 \text { young women heading households } \\
4 \text { younger siblings in youth-headed households }\end{array}$ \\
\hline $\begin{array}{l}\text { Participatory } \\
\text { workshops }\end{array}$ & $\begin{array}{l}\text { 3 Workshops with } 34 \text { young people } \\
\text { (1 in each research location: Kampala, } \\
\text { Nshamba, Kagera region \& Mbeya) using } \\
\text { a range of methods: } \\
\text { - } \quad \text { focus groups with older and younger } \\
\text { siblings } \\
\text { - } \quad \text { bean time-use exercise } \\
\text { - } \quad \text { ranking of needs and priorities } \\
\text { - } \quad \text { art posters } \\
\text { - drama and music performances } \\
\text { - Workshops with } 25 \text { NGO staff and } 14 \\
\text { community leaders } \\
\text { (1 in each research location: Kampala, } \\
\text { Nshamba, Kagera region \& Mbeya) using: } \\
\text { - } \text { pmall breakout discussion groups } \\
\text { presentation of young people's video } \\
\text { performance \& feedback plenary } \\
\text { discussions }\end{array}$ & $\begin{array}{l}\text { Kampala workshop: } \\
3 \text { young men heading households } \\
3 \text { young women heading households } \\
6 \text { younger siblings in youth-headed households } \\
\text { Nshamba workshop: } \\
3 \text { young men heading households } \\
3 \text { young women heading households } \\
5 \text { younger siblings in youth-headed households } \\
\text { Mbeya workshop: } \\
3 \text { young men heading households } \\
2 \text { young women heading households } \\
6 \text { younger siblings in youth-headed households } \\
\text { Kampala workshop: } \\
13 \text { NGO staff \&1 community leader } \\
\text { Nshamba workshop: } \\
6 \text { NGO staff \& } 9 \text { community leaders } \\
\text { Mbeya workshop: } \\
6 \text { NGO staff \& } 4 \text { community leaders }\end{array}$ \\
\hline
\end{tabular}

In Tanzania, the workshops were conducted in Kiswahili with some interpreting/facilitation assistance from NGO workers. In Uganda, support workers arranged transport for the young people living in rural areas to attend the Kampala workshop and a local facilitator helped to interpret from English to Luganda. The workshop with NGO staff and community leaders was conducted in English. Participants received a summary report in Luganda, Kiswahili or English and expense payments to compensate them for their time and contribution to the research. Participants' accounts have been anonymised throughout the paper.

CRuth Evans 12/01/2012.

Please cite this article as: Evans, R., (2012) 'Sibling caringscapes: Time-space practices of caring within youthheaded households in Tanzania and Uganda', Geoforum, doi:10/1016/j.geoforum.2012.02.004. 
This paper is based predominantly on analysis of the interviews, focus groups and participatory diagramming activities conducted with young people. Initial findings about gender differences in the time spent on caring activities were verified in the workshops through the use of a time-use bean diagram. Each participant (both older and younger siblings) was asked to indicate the number of hours they spent on different categories of activities on each day in a typical week ( 1 bean represented 1 hour). The findings about time allocations discussed in the following section are presented with an awareness of the potential problems of time-use data. Firstly, self-reported recall methods may underestimate the time taken for some activities compared to direct observation methods. Gendered and age-related norms are also likely to influence girls' and boys' perceptions of their use of time and the valuing of different activities. Young people completed the diagram in a group setting with their peers present (1 girl and 1 boy each completed a separate flip-chart sheet simultaneously, while their peers watched/ helped to explain the categories and I recorded the final number of beans each participant allocated to each category on a separate A4 sheet) (see Figure 1). This may have resulted in the over-reporting of some activities and the nonreporting of other activities which are not considered important, which are taken for granted or which are perceived as embarrassing (Robson, 2004). Girls and young women may have underestimated the time they spent in domestic and childcare activities since these are constructed as part of their 'natural' gendered roles and responsibilities within the family which they have engaged in from an early age, while boys and young men may have overreported these tasks, since their involvement in this work subverts conventional gender norms. Young people may also have been influenced by/copied their peers' responses, 
although it was unlikely that they would remember the exact number of beans a previous participant had allocated to a particular category.

\section{INSERT FIGURE 1 HERE}

The data collection approach (in this instance the use of a bean to represent one hour for a particular category of activity) also made it difficult to capture smaller segments of time (although some young people indicated half hour time periods) and to indicate simultaneity of caring practices, such as supervision of children in the home while undertaking other activities. Young people were asked to detail their activities over a typical week. However, seeking perceptions of a typical week is considered less accurate than asking respondents to recall the previous 24 hours (Budlender, 2010a). These time allocations cannot be seen as representative of young people heading households in Tanzania and Uganda, since the exploratory research was based on a very small sample.

Despite these limitations, small-scale qualitative, participatory research offers several methodological advantages in terms of providing in-depth insights into the complexity of young caregiving in the context of HIV. Interviews and participatory methods were particularly appropriate in exploring young people's perceptions, emotions and caregiving practices, which large-scale quantitative methods would be unlikely to capture. The participatory diagramming approach enabled me to share initial findings about gendered differences in young people's caring responsibilities with participants and gather further data about the time-space dimensions of their care work. Seeking information about young people's activities on each day of a typical week meant that I could explore differences 
between school/ work days and weekends, resulting in a more accurate overall picture of the average number of hours of care work young people undertake each week. It also provided an opportunity for discussion about the differences between younger and older siblings' and girls' and boys' paid and unpaid work in an informal setting.

Allocating beans to different boxes on a large flip-chart diagram in a group setting also aimed to be more fun and engaging than completing individual exercise sheets and enabled young people with low levels of literacy to participate more easily. Peers helped their siblings/ those with low levels of literacy to complete the bean exercise and sometimes reminded them about household responsibilities and activities they had forgotten to mention. Young people's use of the categories of care work when completing the diagram raised further questions about which activities should be included under the different headings and enabled me to refine my initial categorisation. Furthermore, participatory approaches to analysis, feedback and dissemination are often regarded as a particularly appropriate way of enabling the voices of marginalised groups to influence policy and practice (Coad and Evans, 2008; Van Blerk and Ansell, 2007b). The time-use exercise produced striking evidence about the mean number of hours young people spent per week on care work in that locality that could be quickly collated, analysed and discussed with NGO staff and community leaders in the workshop the following day.

\section{Sibling caringscapes}

\subsection{Time-space routines of caring}


A sibling caringscapes perspective draws attention to the time-space patterning of everyday caring tasks and activities by different actors and the social arrangements for the provision of care across locales. In Tanzania and Uganda, the research found that, in most instances, the eldest co-resident sibling in the household (regardless of gender) considered that they had more caring responsibilities than their younger siblings. When asked to describe a typical day, young people mentioned a wide range of productive and social reproductive activities that they performed according to a daily routine across different locales. These activities can be categorised under the broad headings of 'income earning', 'household chores', 'child care', 'self care', 'household management' and 'community engagement', as summarised in Table 2.

Table 2: Young people's activities in sibling-headed households (see also Evans, 2010)

\begin{tabular}{|l|l|}
\hline Activity & Examples \\
\hline $\begin{array}{l}\text { Income } \\
\text { earning }\end{array}$ & $\begin{array}{l}\text { Cultivating crops and produce for sale, rearing livestock, casual agricultural and } \\
\text { construction work, fishing, working in a factory, shop or bar, selling produce, } \\
\text { cooked food, charcoal and other goods, domestic work, running errands for } \\
\text { neighbours, begging }\end{array}$ \\
\hline $\begin{array}{l}\text { Household } \\
\text { chores }\end{array}$ & $\begin{array}{l}\text { Cooking, washing dishes, sweeping, cleaning and tidying, fetching water and } \\
\text { firewood, laundry, heating water for baths, shopping, cultivating food for } \\
\text { consumption, tending livestock, cutting wood, running errands }\end{array}$ \\
\hline Child care & $\begin{array}{l}\text { Bathing, dressing and washing siblings, getting siblings ready for school, } \\
\text { supervision, giving advice and guidance, resolving arguments and conflict between } \\
\text { siblings, help with school work, health care when siblings are ill, reminding them } \\
\text { to take medication }\end{array}$ \\
\hline Self care & $\begin{array}{l}\text { Personal care, taking medication, getting ready for school, private study, } \\
\text { developing life skills and livelihood strategies etc. }\end{array}$ \\
\hline mousehold & $\begin{array}{l}\text { Allocating tasks, paying school contributions, organising school/vocational } \\
\text { training, budgeting, resolving financial problems, future planning and decision- } \\
\text { making }\end{array}$ \\
\hline $\begin{array}{l}\text { Community } \\
\text { engagement }\end{array}$ & $\begin{array}{l}\text { Maintaining social networks, seeking support from and cooperating with others, } \\
\text { participating in neighbourhood, school, faith community, youth and NGO } \\
\text { meetings, activities and events, playing and spending time with friends. }\end{array}$ \\
\hline
\end{tabular}

In the workshops, young people confirmed the relevance of these different categories of care work. While most of these activities took place predominantly in and around the social space of the household, income earning and community engagement activities were usually reliant ORuth Evans 12/01/2012.

Please cite this article as: Evans, R., (2012) 'Sibling caringscapes: Time-space practices of caring within youthheaded households in Tanzania and Uganda', Geoforum, doi:10/1016/j.geoforum.2012.02.004. 
on young people's interactions and mobility beyond the immediate household. Young people developed supportive relations with neighbours, friends and other community members in their neighbourhood and beyond to secure resources to meet the household's needs. Some neighbours and friends provided practical support with young people's caring and domestic responsibilities, such as checking on beans cooking while children were at school, helping when siblings were ill, providing cooked meals and offering young people work or errands to do in exchange for payment or food. Some young people developed strong relationships with their peers who they worked with, for example, cooking fried cassava for sale in the neighbourhood, helping on each others' farms and doing volunteer work for older people in exchange for a small payment. Several aspects of young people's household chores also provided opportunities for socialising with their peers and for spatial mobility outside the household, such as fetching water and firewood, washing clothes, cultivating food, tending livestock, running errands.

Young people's accounts suggest that sisters heading households had greater and more direct involvement in childcare and domestic work within the home than young men. Although siblings of both genders often shared household tasks, young people's care work appeared to reproduce conventional norms about the gendered division of labour within the household and other public and private locales. Household chores tended to be more evenly shared and negotiated between siblings when the eldest sibling was male, in comparison to households headed by an eldest sister. Isack (aged 12, Uganda), for example, said that his older brothers (who did casual work) expected him to prepare the meal every day: 'if I come back at school, I have to make sure that food is ready and they find it when it is ready'. Sisters heading households appeared to be in a weaker bargaining position compared to brothers heading 
households regarding the allocation of household chores to younger siblings, particularly younger brothers, due to gendered expectations of girls' responsibilities for domestic work.

These preliminary findings about the gendered and age-related dynamics of siblings' caring routines were verified in the workshops through the time-use exercise. Table 3 presents the average number of hours per week participants reported doing each category of activity, based on the collated findings from the workshops in Kampala, Nshamba and Mbeya, disaggregated according to gender and position within the household.

Table 3: Average number of hours per week of different activities of young people living in youthheaded households, by gender and position in household

\begin{tabular}{|l|cccc|}
\hline Activity & \multicolumn{3}{|l|}{ Average (mean) number of hours per week } \\
\cline { 2 - 5 } & $\begin{array}{c}\text { Young women } \\
\text { and girls } \\
\text { heading } \\
\text { households }\end{array}$ & $\begin{array}{c}\text { Young men and } \\
\text { boys heading } \\
\text { households }\end{array}$ & $\begin{array}{c}\text { Younger girls } \\
\text { living in } \\
\text { youth-headed } \\
\text { households }\end{array}$ & $\begin{array}{c}\text { Younger boys } \\
\text { living in } \\
\text { youth-headed } \\
\text { households }\end{array}$ \\
\hline $\begin{array}{l}\text { Income earning } \\
\text { Household chores }\end{array}$ & 11 & 34 & 6 & 5 \\
Child care & 21 & 19 & 22 & 14 \\
Self care & 27 & 31 & 3 & 2 \\
Household management & 26 & 33 & 23 & 11 \\
Community engagement & 11 & 19 & 0 & 1 \\
Total: average hrs per & 15 & 16 & 11 & 13 \\
week spent on all activities & 111 & 152 & 65 & 46 \\
\hline
\end{tabular}

Young men's perceptions of sibling caregiving predominantly in terms of their 'breadwinning role' in earning income to support the family are supported by the time-use data. Boys and young men heading households reported that they spent on average 34 hours per week earning money to support the family, while girls and young women heading households in contrast spent much less time (average of 11 hours a week) earning money (see Table 3 ).

These findings are related to gendered constructions of care and young women's reduced CRuth Evans 12/01/2012.

Please cite this article as: Evans, R., (2012) 'Sibling caringscapes: Time-space practices of caring within youthheaded households in Tanzania and Uganda', Geoforum, doi:10/1016/j.geoforum.2012.02.004. 
access to employment opportunities in Tanzania and Uganda, as previous research in a range of African contexts has shown (Chant and Jones, 2005; Langevang, 2008). Although income earning is not usually categorised as unpaid care work in time-use studies (Budlender, 2010a), it forms a crucial element of young people's care work in families affected by HIV, since young people need to replace the loss of a parent's/ adult relative's income resulting from illness or death (Evans and Becker, 2009).

Young women heading households confirmed that they found it difficult to allocate household chores to younger male siblings and reported spending more time performing household chores (21 hours per week) and managing the household ( 26 hours per week) in comparison to young men (19 hours per week on household chores; 19 hours per week on household management). However, the gendered division of labour is not as pronounced as might be expected. Young men were responsible for activities conventionally perceived as 'women's work'; they reported spending almost as much time as young women doing household chores and more time engaged in childcare. This suggests that age and sibling birth order are likely to be more significant than gender in determining young men's involvement in care and domestic work in sibling-headed households when they lack sisters perceived as old enough to perform these tasks. In such situations, older brothers heading households are likely to allocate domestic tasks to younger brothers, as well as to undertake more childcare and household chores themselves. These findings about young men's and boys' involvement in domestic and care work refute broad generalisations that women and girls do all the unpaid care work in Tanzanian society and are supported by Budlender's (2010b) analyses of time-use data from Tanzania. Similarly, Punch's (2001) research in 
Bolivia concluded that age and sibling birth order may be more significant than gender in determining household divisions of labour.

Analysis according to sibling birth order position confirms that eldest siblings have significantly higher levels of responsibility for household management (26 hours for eldest sisters; 19 hours for eldest brothers), child care (27 hours for eldest sisters; 31 hours for eldest brothers) and income-earning activities (11 hours for eldest sisters and 34 hours for eldest brothers) than their younger brothers and sisters, who had minimal responsibilities for these tasks. However, younger siblings spent considerable amounts of time undertaking household chores (girls even reported spending slightly more time than their older sisters) and self care activities. For younger siblings, the category of 'community engagement' included playing and spending time with friends, which older siblings reported was more limited for themselves; 'community engagement' for them represented predominantly time spent seeking support from others and going to the church/mosque. Older and younger boys reported spending longer in community engagement activities outside the household compared to girls, reflecting conventional gender norms about the use of public and private space and boys' and young men's greater spatial mobility and freedom to engage with the wider environment (Katz, 1993).

Overall, the data reveals that older siblings heading households (regardless of gender) regularly undertake substantial caring tasks and younger siblings have significant responsibilities for household chores (particularly girls) and self-care activities. In official surveys in the minority world, children's (and adults') involvement in 50 or more hours of unpaid care per week is regarded as very substantial caregiving at the high end of the 
caregiving continuum, while 20-49 hours a week is regarded as substantial and significant (Evans and Becker, 2009). The categories of 'income earning', 'self care' and 'community engagement' are not usually included in definitions of 'unpaid care' in research and policy (Budlender, 2010a) ${ }^{3}$. However, even if only the categories of 'childcare', 'household chores' and 'household management' are defined as unpaid care work and taking into account the caveats about the time-use exercise and sample size noted earlier, young people heading households participating in the study still had very substantial and significant caring responsibilities (74 hours a week reported by young women and 69 hours a week by young men). When this is combined with the income earning and community engagement activities necessary to sustain youth-headed households, it is clear that sibling caregivers (young women and men) often undertake a very high level of care work at the extreme end of the young caregiving continuum (Evans, 2010). As might be expected, younger siblings reported spending much less time engaged in income earning activities, childcare and household management than their older siblings, but they still had significant responsibilities for household chores and self-care activities. Sibling birth order and age hierarchies within families thus appear to be more significant than gender in influencing which sibling will take

\footnotetext{
${ }^{3}$ In UNRISD time-use surveys, unpaid care work is defined as (unpaid) household maintenance (broadly equivalent to housework), (unpaid) care of persons in one's own household (including unpaid care for children, older people, those who are ill and disabled) and (unpaid) community services and help to other households. Subsistence agricultural activity and the collection of fuel and water for household consumption are categorised as 'productive work', since "in theory, they are activities that one could pay someone else to do and could be sold on the market (and hence are included in the System of National Accounts used for calculating GDP)" (Budlender, 2010a, p.4).
} 
overall responsibility for heading the household following the death of a parent/ adult relative.

While sibling households were headed by both young men and young women, dominant gender norms were reproduced as well as contested through their everyday caring practices. Options for paid employment were more restricted for young women than young men and young women reported spending much less time earning an income compared to young men. Gendered norms meant that older sisters found it more difficult to allocate household chores to their younger brothers than older brothers. The gendered division of labour within the household was not a pronounced as might be expected, however, and boys and young men reported that they were engaged in many household chores, childcare and household management tasks usually associated with women's roles, challenging dominant gender norms.

\subsection{Emotional geographies and temporalities of sibling caregiving}

A sibling caringscape perspective highlights not only caring activities and routines, but also the feelings and subjective positions of different actors involved in caring pathways. Young people expressed a range of different emotions about their caring responsibilities. Many young people felt a moral obligation to look after their siblings following their parent's death and were proud of their caring role. Some young people however, expressed their sadness and regret that extended family members had failed to support them, leaving them with little alternative but to care for their siblings. They commented on the loneliness of the parental role they found themselves taking on for their siblings and several had experienced significant discrimination and harassment as a youth-headed household (Evans, 2011). Amina 
(aged 16), for example, cared for her four younger siblings (aged 6-13), three of whom were living with HIV, in Kampala. She described how her step-father had alcohol use problems, beat them and took the rental income from the property they inherited from their mother for himself rather than leaving it for the children to support themselves. Although he had attempted to rape her and she felt unsafe sleeping in their home, Amina felt a moral obligation to care for her siblings: 'I don't want to leave them alone, because they are my brothers and sisters, because even I wanted to leave them to go away, but I felt sad, because they are positive, no one can help them, even if their father abuses me, but I just live here because of my sisters and brothers, looking after them'. While this is perhaps an extreme example, it reveals the complex, often painful, emotional subjectivities that may be associated with young caregiving.

Although young people expressed profound sadness about the loss of their parents, those who had provided nursing care for their parent felt that their care work was less time consuming than previously. Furthermore, young people in Tanzania who received regular material and educational support from NGOs felt that their circumstances had improved to some extent after their parent's death, since following their identification as 'orphans', they received regular food and health care support and they were able to return to school. Sophia (aged 21, who cared for three younger siblings aged 15-19 and her own daughter, aged 5) in Dar es Salaam, commented: 'Things have changed a lot, because when we lived with our mother, when she was sick, we were in a very difficult situation. But for now we are better, we eat and go to school. What we can't afford now is clothes'. Monthly cash transfers enabled young people in Nshamba to budget and plan their schooling and livelihood activities. Rickson 
(aged 19) valued his independence as the head of the household and enjoyed planning his own timetable for study and domestic chores:

I am happy because I decide what to do, because if I was living with someone else, he/she could have been planning for me some of the things I do not like. But because I live alone, I can plan that this time I do this, I have a timetable to do this and not to do that, when it reaches this time, I have to do this.

Regular material support enabled young people to balance their caring and domestic responsibilities with the demands of their school work and achieve a greater sense of control over their lives, which appeared to enhance their emotional wellbeing.

However, several young people attending school in Tanzania commented on the time pressures they experienced as they struggled to combine their studies with social reproductive activities. In the focus group in Mbeya, young people revealed the considerable emotion work (Hochschild, 1979) involved in sibling caregiving across different locales. Simon (aged 16) worried about providing for his siblings while he was at school, which affected his concentration and academic performance there:

The job of raising children is not a small task. It's difficult because even when you're at school you're still thinking 'oh what's going on at home? Is there going to be enough food?' So when you're studying, you're thinking about two things - you're thinking about studying and you're thinking about home. And sometimes, this becomes something which is really tiring. To go to school, to cook, look after the 
children and then to go to school and it starts all over again. And then there are other days when you just have to ask for help. Sometimes you have to ask someone to help you with flour and with soap for washing clothes.

Similarly, Tausi (aged 23) who cared for four younger siblings and was studying in secondary school commented: 'When I leave for school, I'm already thinking about home, what I'm going to have to buy. When I get there, I'm thinking about the little ones and at any moment I might be kicked out and I'm just there to study'. This reveals the highly embodied nature of young people's simultaneous caring practices across different locales. Young people engaged in considerable emotional labour while doing other activities at school and/or work, making plans for how to meet the needs of the household and worrying about where the next meal would come from. As Strazdins et al. (2011, p.548) comment, 'caring for others requires a close interlocking with their needs, the timing of which is hard to predict, schedule and contain, especially across different locations'.

Young people's accounts also highlight the repeated nature of reproductive work which was 'never done' and was often an ongoing struggle to meet the household's basic needs. The daily grind of chronic poverty and young people's relatively powerless position as orphans living alone in a youth-headed household needs to be understood within the broader landscape of care, characterised by very limited access to public healthcare and welfare support, gendered and age-related norms of care that usually provide for orphans within the extended family and stigma and discrimination in the community. This landscape of care diminishes young people's autonomy and capacity to act, shaping their subjective responses to caring responsibilities and time-space practices of caring. 
A rhythmanalytical approach draws attention to the potential conflict or 'arrhythmia' between linear and cyclical rhythms of everyday life and how this is experienced through the body (Lefebvre, 2004). Young people living in rural areas who had access to land and were supported to continue their education commented on the time scarcity they experienced, particularly during the main planting and harvesting seasons, as they attempted to balance the need to care for their siblings, attend school, engage in private study and produce food on their farm. Tausi, for example, said: 'We used to have a farm and we used to grow maize and other things but now because I'm trying to study things aren't as easy'. Such time scarcity compromised the household's food security and siblings' health and wellbeing (Strazdins et al., 2011). Indeed, Hamisa (aged 19) who lived alone with her cousin (aged 9) in a village in Kagera region, Tanzania explained how time scarcity in preparing meals after school had led to long term health problems:

A problem is that when we come from school, we eat cold food because we cook it the previous night. Her [younger cousin's] classes end at 2pm and my classes end at 4pm, so when we come home we have no time to cook. So, if we don't cook at night then we will not have our lunch and we won't eat anything until dinner time. So you find we eat cold food, and it is not a good meal [...] and when you eat just one meal, you can get a disease. I went to the hospital and they told me that I have ulcers. This is because I spend the whole day at school. Sometimes I eat one meal at night, so I got the problems of ulcers. Up 'til now, I have not been healed completely.

CRuth Evans 12/01/2012.

Please cite this article as: Evans, R., (2012) 'Sibling caringscapes: Time-space practices of caring within youthheaded households in Tanzania and Uganda', Geoforum, doi:10/1016/j.geoforum.2012.02.004. 
Many young people heading households reported that they usually only prepared one meal a day, in the evenings after school/work. This could be especially problematic for younger siblings living with HIV who needed an adequate, nutritional diet for anti-retroviral therapy to be effective and to avoid HIV-related illnesses.

Joseph (aged 20, Tanzania) described how he tried to juggle the competing time demands of school work and household chores by 'doing everything quickly', but acknowledged that this was exhausting and could have a negative effect on his academic progress: 'I don't have much time and when you come home you're tired and you have so many things to do and you just want to sleep. So everything I do, I have to do it quickly'. As studies in other African countries have shown (Porter, Hampshire et al., 2011), balancing care work with other activities was especially problematic for young people who lived considerable distance away from school, since the walk of several kilometres to school each day took up valuable time and energy. If they arrived at school late, young people reported that they often had to do hard labour outside for several hours as a punishment, which further increased their fatigue and limited their academic progress. Young people expressed frustration about the lack of understanding among teachers of their care work and the physical and mental exhaustion they experienced. Joseph commented:

They [teachers] don't understand that we come from far away and all the things we have to do. They do not understand all the work we have to do [...]. And so it is best for us if we just do the punishment they give us. Sometimes you can find us outside for four hours, and then you are just thinking about your younger brothers and sisters or about what is going on in the classroom. Four hours you are outside. Even one hour 
is enough, after two hours you enter the classroom and you're already tired from the work they have given you. And then you can't listen, you want to listen but you can't listen to what they're saying.

Young people's accounts therefore reveal how embodied time-space practices of caring often conflict with the linear rhythms of schooling and work, as well as the cyclical rhythms of everyday life, such as the body's daily needs for food, rest and sleep and seasonal agricultural labour demands. This resulted in time scarcity which could have negative impacts on young people's health and educational outcomes. Young people in Tanzania who received regular external support enjoyed their autonomy in being able to manage the household and plan their own timetable for study and care work. However, several young people's accounts reveal the emotional labour involved in simultaneous caregiving across a range of locales, and the time scarcity and 'arrhythmia' that this may cause for individual bodies. For some young people, the struggle to balance time-space practices of caring with a rigid school timetable, the seasonal demands of agricultural food production and available opportunities for casual work that they needed to chase in order to sustain themselves and their siblings led to fatigue and feelings of anxiety, frustration, loneliness and despair about the future. As Simonsen (2005, p.8) notes, 'emotions and affections, private life and its symbols cannot submit to cumulative and linear processes'. Furthermore, as I explore in the next section, emotional geographies of sibling caregiving may intersect with social expectations of young people's age and lifecourse stage to constrain their future transitions to adulthood.

\subsection{Relational lifecourse transitions and imagined futures}

CRuth Evans 12/01/2012.

Please cite this article as: Evans, R., (2012) 'Sibling caringscapes: Time-space practices of caring within youthheaded households in Tanzania and Uganda', Geoforum, doi:10/1016/j.geoforum.2012.02.004. 
A caringscape perspective foregrounds the importance of understanding how caring pathways are connected to socially expected lifecourse transitions, such as completing school, commencing employment, marriage, pregnancy and childbirth among others. Within a globalised world, achieving a high level of education and financial autonomy may be regarded as increasingly important goals for many young people, which may prolong the period of 'youth' and postpone young people's adoption of conventional markers of 'adulthood' such as marriage (Ansell, 2004).

The research in Tanzania and Uganda suggests that sibling caregiving represented a long term commitment which was sustained as young people grew older, in spite of socially expected lifecourse transitions. In Tanzania and Uganda (as in many other African countries: Ansell, 2004; Langevang, 2008), marriage continues to be considered the key marker of 'adulthood'. Patrilocal marriage practices and patrilineal inheritance norms mean that boys and young men have a greater claim to their late parents' land and property than their sisters, who are expected to marry and move away from their natal home to their husband's household. Service providers and young people thus considered it more difficult for young women to get married and stay to care for their siblings in the inherited parental home than for young men. Furthermore, as Makungu (2011) found, young women living alone with their siblings were considered to be particularly vulnerable to sexual abuse, coercion, pregnancy and/or early marriage. In contrast, some service providers thought that young men heading households might be more inclined to marry earlier than usual and stay with their siblings in the inherited parental home due to gendered expectations that a wife would take over responsibility for domestic duties and thereby alleviate their caring responsibilities. However, young people highlighted the tensions and difficulties that could arise for younger 
siblings if an older brother brought a wife to live in their home; the wife's resentment at having to care for her husband's younger siblings could result in harassment and the need for siblings to move away to live with foster relatives, which was perceived as undesirable by both older and younger siblings.

Marriage did not therefore appear to be an immediate priority for most young people interviewed, despite its importance as a marker of adult status. Indeed, both young men and young women regarded completing their education and achieving a level of financial security as much higher priorities for themselves and their siblings than marriage. Young people's educational outcomes, employment opportunities and future life chances were shaped to a large extent by their caring responsibilities and the availability of external support. Young people in Tanzania attending secondary school with the support of NGOs placed a high value on continuing their studies as long as possible so that they would be able to obtain a good job and support their siblings in future. Rickson tried to prepare his younger siblings (aged 9 and 13) to manage without him so that he would be able to pursue his A-level studies away from home in future:

I think they will manage, one time when I had to travel for one month, I left them alone. But they managed to live well themselves. They said that at the beginning they were scared but they then got used to it. They told me that even when you are not here, we can stay by ourselves. So I told that that it is good to learn to be alone, so that even when I am not there, there should not be any problem...

CRuth Evans 12/01/2012.

Please cite this article as: Evans, R., (2012) 'Sibling caringscapes: Time-space practices of caring within youthheaded households in Tanzania and Uganda', Geoforum, doi:10/1016/j.geoforum.2012.02.004. 
When the eldest sibling moved away for study or work, the next eldest sibling was usually expected to assume primary responsibility for looking after the younger children.

Despite expressing their concerns about pressures to engage in sexual relationships with older men in return for food and money, young women heading households also emphasised their long term commitment to care for their siblings. Sophia (aged 21) who cared for three younger siblings and her own young daughter in Dar es Salaam said that she would continue to support her siblings until they completed school and were able to support themselves financially, even if she had married and moved out of the household by then:

When you are married, you are not allowed to live in your house, you have to live there. But even when I live there, it will still be my responsibility to make sure my younger brothers and sisters have reached the stage that I have reached. It is not good to just to go there...you have to make sure that you have education, you have your job and you have money so that you can help your brothers and sisters.

In comparison to the young people in Tanzania, the educational outcomes, employment opportunities and imagined futures for young people interviewed in Uganda appeared to be more severely constrained by chronic poverty and their caring responsibilities ${ }^{4}$. Several young people had not been able to continue their studies after primary school, while some

\footnotetext{
${ }^{4}$ The differences between young people's educational status and living circumstances in Tanzania and Uganda are due in part to the recruitment of the sample through NGOs with differing levels of support available to orphans and vulnerable children.

CRuth Evans 12/01/2012.

Please cite this article as: Evans, R., (2012) 'Sibling caringscapes: Time-space practices of caring within youthheaded households in Tanzania and Uganda', Geoforum, doi:10/1016/j.geoforum.2012.02.004.
} 
were forced to drop out of secondary school after one or two years due to poverty and the need to support their siblings. Although they wanted to obtain good jobs with a regular income, they generally had low aspirations and several expressed a lack of hope for the future.

Young people's experiences suggest that sibling caregiving may prevent young people from taking up employment opportunities and pursuing migration strategies that would help to reduce their vulnerability to chronic poverty over the lifecourse. Tausi (aged 24 at the time of the workshop) who cared for four younger siblings in Mbeya, for example, wanted to start her own business trading cloth, but felt constrained by her caring responsibilities: 'I'm not able to travel far for work for myself because of being afraid to leave them [her siblings] on their own'. Similarly, the caring pathway of Jamiru, who lived in a small town near Kampala, reveals how young people's education, migration strategies and long term livelihood opportunities may be curtailed by their caring responsibilities, which in turn may increase their vulnerability to the intergenerational transmission of poverty (see Box 1). 


\section{Box 1: Jamiru's caring pathway, Uganda}

Jamiru (aged 16) started caring for his six younger siblings (aged $4-10$ years) when he was 13, following the onset of his father's illness. He tried to continue at school, but found it too difficult to combine his schooling with his care work and the need to earn an income to support the household. Jamiru's father had been a traditional healer and had a small shop and some rental property in a small town near Kampala. He had three wives, two of whom had lived nearby on their farms which they cultivated for food consumption. Jamiru's uncle, who lived nearby, and the eldest siblings helped to care for their father during his long illness in hospital. Their father left a will which stated that his house and rental property should be left to his children and appointed their uncle as the guardian of the children until they came of age.

Following his father's death, Jamiru and his older brother (aged 18) migrated to Kampala to seek casual work as construction porters. When they returned after some time, they found that their younger siblings (who they had left in the care of their uncle) were living in poor conditions and their home had been neglected. The brothers decided that Jamiru should stay at home to look after the younger siblings while his older brother returned to work in Kampala and sent remittances he saved for the family whenever he could.

Jamiru found work selling goods by motorbike for a small company, but was occasionally not paid for the work and sometimes there was no work available. He usually earned around 35,000 Ush [equivalent to 21 US\$ at the time of research] per month. He also worked with his peers doing casual agricultural labour, fetching water for people and cooking cassava for sale in the neighbourhood as a small additional source of income. Jamiru hired land to cultivate food for consumption and for sale. Jamiru explained that if he could not raise the money for the hire of the land, he paid the landlord in kind with the food they produced.

Jamiru was committed to caring for his younger siblings and planned to stay together with them until they had grown up. When asked what would make life easier in future, Jamiru said (via the translator), 'that he always has work to do, he is employed, so that he's earning an income to continue supporting his young ones, to see that his young ones are in school'.

In a context in which low educational outcomes are common, the only available paid work is irregular and unreliable, and mobility between urban centres is perceived as important for young people to develop the skills, social networks and access to employment opportunities needed to achieve future financial security (Langevang, 2008; Punch, 2002), young people's inability to make successful transitions to paid work due to their caring responsibilities may lead to a sense of failure and regret that compounds their level of impoverishment. This may result in young people, such as Tausi and Jamiru who were unable to migrate to pursue headed households in Tanzania and Uganda', Geoforum, doi:10/1016/j.geoforum.2012.02.004. 
employment opportunities, remaining in a liminal position between 'childhood' and 'adulthood' for considerable periods, unable to make the transitions that are socially expected at their age and life stage. This may limit their future employment prospects and options to avoid chronic poverty over the lifecourse.

Despite these structural constraints, however, Jamiru's caring pathway also reveals how young people are able to exercise some autonomy over how they respond to the severe social and economic consequences of AIDS (Jarvis et al., 2011). By constantly seeking out new employment and agricultural opportunities to support themselves and their siblings and adapting migration and livelihood strategies in order to accommodate their caring responsibilities, young people express their agency, although their options are often severely constrained. As Klocker (2007, p85) discusses, while young people's employment opportunities may be highly restricted by poverty and socio-cultural factors, resulting in a lack of viable alternatives, their agency in the process cannot be completely denied: 'they understand and actively negotiate the expectations and power relations that surround them while making decisions aimed at improving their own lives and those of their families'. She refers to decisions and everyday actions that are carried out in highly restricted contexts as 'thin agency'. Young people's choices to continue to care for their siblings until they complete their education and are able to support themselves could be regarded as an expression of 'thin agency' that helps to strengthen existing emotional bonds within the family and foster interdependent relations between siblings, which are likely to be sustained and reciprocated throughout the lifecourse (Punch, 2002).

\section{Conclusion}

CRuth Evans 12/01/2012.

Please cite this article as: Evans, R., (2012) 'Sibling caringscapes: Time-space practices of caring within youthheaded households in Tanzania and Uganda', Geoforum, doi:10/1016/j.geoforum.2012.02.004. 
Most studies of young caregiving focus on situations where young people care for chronically ill or disabled parents/ adult relatives, and childcare for siblings is regarded as a secondary aspect of children's caring roles. This study reveals that in the context of high levels of orphanhood in eastern and southern Africa, some young people have substantial caring responsibilities for younger (non-disabled) siblings. They seek to replace the loss of their parent's income, grow food and bring up their younger siblings, sustaining their households through productive, social reproductive and community engagement work. Participatory time-use data suggests that older siblings of both genders regularly undertake substantial care work (74 hours a week reported by young women and 69 hours a week on average reported by young men) that places them at the very high end of the caregiving continuum. Their daily routines can lead to time scarcity, which is detrimental to their health, education, future employment prospects and mobility.

Furthermore, young people's experiences reveal the highly embodied, repeated nature of such time-space practices of caring across different locales. The regular, substantial care work that young people undertake according to a daily routine often conflicts with linear rhythms of schooling and work, in addition to the cyclical rhythms of everyday life. The resulting time scarcity and 'arrhythmia' had negative physical effects on young bodies, including tiredness, fatigue, poor nutrition and health problems. The deeply emotional effects of the on-going struggle to meet their own and their siblings' needs and avoid chronic poverty following parental death and bereavement also had long term effects on young people's emotional wellbeing and capacity to act over time.

CRuth Evans 12/01/2012.

Please cite this article as: Evans, R., (2012) 'Sibling caringscapes: Time-space practices of caring within youthheaded households in Tanzania and Uganda', Geoforum, doi:10/1016/j.geoforum.2012.02.004. 
Indeed, young people's lifecourse transitions are shaped by caring pathways which shift over time and space, within a broader landscape of care. 'Successful' transitions to adulthood, such as completing education, migrating for work opportunities or achieving the financial means to marry and support their own families may be delayed or restricted because of young people's caring responsibilities. This challenges individualised understandings of youth transitions, such as Giddens' (1991) notion of transition points as a 'reflexive project of identity' that individuals engage in by assessing risks and making decisions. Rather, the research reveals the ways that youth transitions in the majority world may be shaped by interdependent, reciprocal relations within the family and community which tend to be maintained throughout the lifecourse (Punch, 2002). This may mean, however, that young people are caught in a liminal position between discourses of childhood and adulthood, unable to make socially expected transitions linked to their age and lifecourse stage. Meanwhile, parenting roles in bringing up children are usually associated with adulthood. Sibling caregiving in youth-headed households thus deviates from local and global norms of childhood, youth, parenting and household formation and was sanctioned by the community through stigma and marginalisation (Evans, 2011).

The emotional geographies and temporalities of caregiving, combined with wider structural inequalities that position orphaned youth as relatively powerless within the community, thus result in highly restrictive contexts in which young people are only able to exercise 'thin agency' (Klocker, 2007). Young people's lifecourse transitions are both enabled and constrained by familial responsibilities to their siblings, as well as by gender and age hierarchies and other socio-cultural norms, access to resources and livelihood opportunities in rural and urban areas and individuals' own physical and emotional wellbeing. As Klocker 
(2007, p.85) notes, however, structures, contexts and relationships are not static, but rather are constantly changing and can act as “'thinners' or 'thickeners' of individuals' agency, by constraining and expanding their range of viable choices". This reveals the importance of understanding the changing contexts and relations that mediate individuals' capacity to act and exercise 'relational autonomy' over caring pathways and lifecourse transitions (Evans and Atim, 2011).

The findings from Tanzania and Uganda highlight the need for greater recognition among teachers and family support workers of the time pressures that young people may be under in caring for siblings and earning an income to sustain the family, while struggling to keep up with their school work, arrive at school on time, meet the costs of school uniforms and materials and trying not to miss too many classes due to their own or their siblings' illness. Greater flexibility in school timetables is needed to accommodate young people's care work and provide a more supportive educational environment, rather than punishing them for their caring responsibilities. Young people identified their needs and requirements for support as: food, good quality housing, healthcare, education, financial support, employment and regular income, emotional support, information and guidance, capital for income generation and life skills training (listed here in the order of priority that young people ranked in the workshops). Alongside addressing young people's immediate practical needs, several strategic needs can be identified that would help to alleviate young people's care work, challenge their low social status as youth-headed households and enable them to pursue their imagined futures. These include:

- recognising and valuing the extensive care work young people undertake within their families and communities, within a broader ethic of care (Evans and Becker, 2009) 
- providing practical assistance with household work and sibling care to reduce the hours of young people's care work and reduce negative outcomes for their education, health, employment prospects and mobility

- flexible educational, vocational training and employment opportunities to enable young people to catch up on missed schooling and educational qualifications, gain relevant skills and experience and pursue their aspirations

- opportunities for peer support and collective community-based mobilisation to tackle the stigma, harassment and unequal gender and generational relations that lead to the exploitation, abuse and marginalisation of young people living in youth-headed households (Evans, 2011).

Further research is needed to survey a larger, more representative sample of young people in Tanzania, Uganda and other African countries to gain an understanding of their usual time contributions to their households, in addition to analysing the specific time-space practices of young people engaged in high levels of care work for a range of different family members and others in the community. This would enable comparisons to be drawn between the extent and nature of care work that young people perform in different contexts. Furthermore, the paper reveals the usefulness of the concept of 'caringscapes' (McKie et al., 2002), informed by a lifecourse perspective, to analyse the complex, interwoven spatialities and temporalities of caring pathways. This time-space framework, combined with the rhythmanalytical approach (Lefebvre, 2004) sheds light on the ways that individuals embody the practices, routines and rhythms of everyday life and exercise agency within broader landscapes of care that may be highly compromised. 


\section{References}

Ansell, N., 2004. Secondary schooling and rural youth transitions in Lesotho and Zimbabwe. Youth and Society 36(2), 183-202.

Ansell, N., van Blerk, L., Hajdu, F., Robson, E., 2011. Spaces, times and critical moments: a relational time-space analysis of the impacts of AIDS on rural youth in Malawi and Lesotho. Environment and Planning A 43, 525-544.

Bauman, L., Foster, G., Johnson Silver, E., Gamble, I., Muchaneta, L., 2006. Children caring for their ill parents with HIV/AIDS. Vulnerable Children and Youth Studies 1(1), 1-14.

Becker, S., 2007. Global perspectives on children's unpaid caregiving in the family: research and policy on 'young carers' in the UK, Australia, the USA and Sub-Saharan Africa. Global Social Policy 7(1), 23-50.

Becker, S., Aldridge, J., Dearden, C., 1998. Young Carers and Their Families. Blackwell Science, Oxford.

Bowlby, S., McKie, L., Gregory, S., and MacPherson, I., 2010. Interdependency and Care over the Lifecourse. Routledge, Oxford.

Budlender, D., 2010a. What do time use studies tell us about unpaid care work? Evidence from seven countries. In: Budlender, D. (Ed.) Time use studies and unpaid care work.

Routledge, London and New York, pp.1-46.

Budlender, D., 2010b. Tanzania. Care in the context of HIV and AIDS. In: Budlender, D. (Ed.) Time use studies and unpaid care work. Routledge, London and New York, pp. 46-68. Chant, S., Jones, G., 2005. Youth, gender and livelihoods in West Africa: perspectives from Ghana and The Gambia. Children's Geographies 3(2), 185-199. 
Christiansen, C., Utas, M., Vigh, H., 2006. Youth(e)scapes. In: Christiansen, C., Utas, M., Vigh, H. (Eds.) Navigating Youth Generating Adulthood: Social Becoming in an African Context. Nordiska Afrikainstitutet, Uppsala, pp. 9-28.

Cicirelli, V., 1994. Sibling relationships in cross-cultural perspective. Journal of Marriage and the Family, 56(1), 7-20.

Coad, J. and Evans, R. 2008. Reflections on practical approaches to involving children and young people in the data analysis process. Children and Society 22, 41-52.

Conradson, D., 2003. Geographies of care: spaces, practices, experiences. Social and Cultural Geography 4(4), 451-454.

Davies, K., 2001. Responsibility and daily life: reflections over timespace. In: May, J., Thrift, N., (Eds.) Timespace. Geographies of Temporality. Routledge, London and New York, pp.133-148.

Dewilde, C., 2003. A life-course perspective on social exclusion and poverty” British Journal of Sociology 54(1), 109-128.

Elden, S., 2004. Rhythmanalysis: an introduction. In: Lefebvre, H. Rhythmanalysis: Space, time and everyday life. Continuum, London, pp. vii- Xv.

Evans, R., 2010. Children's caring roles and responsibilities within the family in Africa. Geography Compass 4(10), 1477-1496.

Evans, R., 2011. 'We are managing our own lives...': Life transitions and care in siblingheaded households affected by AIDS in Tanzania and Uganda. Area 43(4), 384-396.

Evans, R., Becker, S., 2009. Children Caring for Parents with HIV and AIDS: Global Issues and Policy Responses. The Policy Press, Bristol.

Evans, R., Thomas, F., 2009. Emotional interactions and an ethic of care: caring relations in families affected by HIV and AIDS. Emotions, Space and Society 2, 111-119. 
Evans, R., Atim, A., 2011. Care, disability and HIV in East Africa: diverging or interconnected concepts and practices? Third World Quarterly 32(8), 1407-1424.

Giddens, A., 1991. Modernity and Self Identity: Self and Society in the Late Modern Age. Polity, Cambridge.

Haugen, G., 2007. Caring children: exploring care in post-divorce families. The Sociological Review 55(4), 653-670.

Hochschild, A., 1979. Emotion work, feeling rules and social structure. American Journal of Sociology 85(3), 551-575.

Horton, J., Kraftl, P., 2006. Not just growing up, but going on: materials, spacings, bodies, situations. Children's Geographies 4(3), 259-276.

Jarvis, H., Pain, R., Pooley, C., 2011. Guest editorial: Multiple scales of time-space and lifecourse. Environment and Planning A 43, 519-524.

Katz, C., 1993. Growing circles/ closing circles: Limits on the spaces of knowing in rural Sudan and US cities. In: Katz, C., Monk, J. (Eds.) Full Circles: Geographies of Women over the Life Course. Routledge, London, pp. 88-106.

Kesby, M., 2000. Participatory diagramming: deploying qualitative methods through an action research epistemology. Area 32(4), 423-435.

Kesby, M., Gwanzura-Ottemoller, F., Chizororo, M., 2006. Theorising other, 'other childhoods': issues emerging from work on HIV in urban and rural Zimbabwe. Children's Geographies 4(2), 185-202.

Klocker, N., 2007. An example of 'thin' agency: child domestic workers in Tanzania. In: Panelli, R., Punch, S., Robson, E.,(Eds.) Global Perspectives on Rural Childhood and Youth Routledge, Abingdon and New York, pp. 83-94. 
Kullman, K., Palludan, C., 2011. Rhythmanalytical sketches: agencies, school journeys, temporalities. Children's Geographies 9 (3/4), 347-359.

Langevang, T., 2008. 'We are managing!' Uncertain paths to respectable adulthoods in Accra Ghana. Geoforum 39, 2039-2047.

Lefebvre, H., 2004. Rhythmanalysis: Space, time and everyday life. Continuum, London. LeVine, R., Dixon, S., LeVine, S., Richman, A., Leiderman, P., Keefer, C., Brazelton, T., 1996. Child Care and Culture: Lessons from Africa. Cambridge University Press, New York. Makungu, C., 2011. Young people in self-care: behaviours and experiences in farming households in Kilombero valley, Tanzania, unpublished Master of Arts by Research thesis, University of Durham.

Massey, D., 2005. For Space. Sage, London.

May, J., Thrift, N., (Eds.) 2001. Timespace. Geographies of Temporality. Routledge, London and New York.

McKie, L., Gregory, S., Bowlby, S., 2002. Shadow times: the temporal and spatial frameworks and experiences of caring and working. Sociology 36(4), 897-924.

Meintjes, H., Hall, K., Marera, D., Boulle, A., 2010. Orphans of the AIDS epidemic? The extent, nature and circumstances of child-headed households in South Africa. AIDS Care 22(1), 40-49.

Miller, P., 2005. Useful and priceless children in contemporary welfare states. Social Politics 12(1), 1-39.

Milligan, C., Wiles, J., 2010. Landscapes of care. Progress in Human Geography 34(6), 736754.

Nyambedha, E., Wandibba, S., Aagaard-Hansen, J., 2003. Changing patterns of orphan care due to the HIV epidemic in Western Kenya. Social Science and Medicine. 57, 301-11. 
Payne, R. 2009. Child-Headed Households in Zambia: from concepts to realities.

Unpublished PhD thesis Department of Geography Royal Holloway University of London.

Porter, G., Hampshire, K., Abane, A., Tanle, A., Esia-Donkoh, K., Amoako-Sakyi, R. O., Agblorti, S., Asiedu Owusu, S., 2011. Mobility, education and livelihood trajectories for young people in rural Ghana: a gender perspective. Children's Geographies 9 (3/4), 395-410. Punch, S. 2001. Household division of labour: generation, gender, age, birth order and sibling composition. Work, Employment and Society 15(4), 803-23.

Punch, S., 2002. Youth transitions and interdependent adult-child relations in rural Bolivia. Journal of Rural Studies 18, 123-133.

Robson, E., 2004. Children at work in rural northern Nigeria: patterns of age, space and gender. Journal of Rural Studies 20, 193-210.

Robson, E., Ansell, N., Huber, U. S., Gould, W. T. S., van Blerk, L., 2006. Young caregivers in the context of the HIV/AIDS pandemic in sub-Saharan Africa. Population, Space and Place 12, 93-111.

Skovdal, M., 2011. Examining the trajectories of children providing care for adults in rural Kenya: implications for service delivery. Children and Youth Services Review 33, 1262 1269.

Silk, J., 1998. Caring at a distance. Ethics, Place and Environment 1(2), 165-182.

Simonsen, K., 2005. Bodies, sensations, space and time: the contribution from Henri Lefebvre. Geografiska Annaler 87 B (1), 1-14.

Strazdins, L., Griffin, A., Broom, D., Banwell, C., Korda, R., Dixon, J., Paolucci, F., Glover, J., 2011. Time scarcity: another health inequality? Environment and Planning A 43, 545-559. 
Tanzania Commission for AIDS (TACAIDS), National Bureau of Statistics (NBS) and ORC Macro. 2005. Tanzania HIV/AIDS Indicator Survey 2003-04, Calverton, Maryland, USA: TACAIDS, NBS and ORC Macro

Thurman, T., Snider, L., Boris, N., Kalisa, E., Nyirazinyoye, L., Brown, L., 2008. Barriers to the community support of orphans and vulnerable youth in Rwanda. Social Science and Medicine 66, 1557-1567.

UBOS, 2006. Uganda National Household Survey 2005/2006, Report on the Socio-Economic Module. Uganda Bureau of Statistics, Kampala.

United Nations, 2007. World Youth Report 2007 Young People's Transitions to Adulthood:

Progress and Challenges. United Nations, New York.

Valentine, G., 2003. Boundary crossings: transitions from childhood to adulthood. Children's Geographies 1(1), 37-52.

Valentine, G., 2008. The ties that bind: towards geographies of intimacy Geography Compass 2(6), 2097-2110.

Van Blerk, L., Ansell, N., 2007a. Alternative strategies for care giving in the context of AIDS in Southern Africa: complex strategies for care. Journal of International Development. 19, $865-884$.

Van Blerk, L. and Ansell, N., 2007b. Participatory feedback and dissemination with and for children. Children's Geographies 5(3), 313-324. 


\section{Highlights:}

- Orphaned youth heading households undertake very high levels of care work

- Gendered time-space practices conflict with linear and cyclical rhythms of everyday life

- Time scarcity has negative outcomes on young people's health, education and mobility

- 'Successful' transitions to adulthood are restricted by caring responsibilities

- Changing contexts and relations of care mediate young people's agency 